\title{
Impact of modernization of harvesting in tea plantation to improve the productivity and quality (Camellia spp.)
}

\author{
Veeraiyan Nandagopalan ${ }^{1}$, Thangavelu Balamurugan ${ }^{1}$ and Alakiyamanavalan \\ Lakshmi prabha ${ }^{2}$. \\ ${ }^{1 .}$ PG and Research Department of Botany, National College, (Autonomous), Tiruchirappalli-620 001, Tamil \\ Nadu, India. \\ 2. Department of Plant Science, Bharathidasan University, Tiruchirappalli-620 204, Tamil Nadu, India.
}

\begin{abstract}
Hand plucking is throughout to be the best method of tea harvesting and has evolved with the tea industry to improve the productivity and quality. With good training of pluckers, a high degree of shoots selectively can be achieved and damage to the tea bush is minimal. Where manual labour is in short supply and mechanical methods of harvesting tea have of necessity been considered. Shear harvesting, as an alternative method to machine harvesting. The green leaf biochemical constituents and quality parameters of black teas changed with method of harvesting. Integrated shear harvesting teas were very rich in their green leaf biochemical precursors and had higher contents of black tea quality constituents than machine harvesting tea. The quality decline was mainly due to mechanical injury and non-selective plucking with machine harvesting. However, tea obtained by mechanical harvesting to continuously field over a prolonged period quality was found to be better, but productivity was declined and physiology of the bush affect when machines are not properly used for harvesting.

Keywords: Yield, shear, single men harvesting machine, two man harvesting machine, biochemical parameter and black tea parameter.
\end{abstract}

\section{Introduction}

Tea is one of the popular beverages all over the world due to its special aroma, flavor and health benefits. The crop plant belongs to theaceae and is perennial in nature. All the cultivated tea plants belong to two distinct taxa, viz., Camellia sinensis (L.) O. Kuntze the short leaved "China" plants and Camellia assamica (Masters) Wight, the broad leaved " Assam" cultivar. The "Cambod" variety, a subspecies of the latter, is classified as Camellia assamica spp. lasiocalyx (Planchon ex watt) Wight (1959). "China", [?]"Assam", "Cambod", "jats" and a large number of their hybrids are exploited commercially in majority of the tea plantations.

Style of plucking is very important for to produce of high quality of black tea and several attempts have been made to establish the correct plucking standards. Black tea quality as measured by theaflavin and thearubigin levels. Coarsely harvested leaf produced black tea with low theaflavins and thearubigin. Reduction in theaflavins levels was attributed to the low levels of catechins and the plucking standard became coarse (Forrest and Bendall, 1969). Although the thearubigin levels were expected to follow the theaflavins pattern, the converse was observed.

The profitability of the operation is governed by the quantity and quality of the tea plucked shoots (Mamedov and Dzhafarof, 1974: Baruah et al., 1896). For long term tea leaves are harvested by hand-plucking without causing mechanical injury and manufactured under optimal conditions in order to maintain quality (Palmer-Jones, 1977, Owour et al., 1987). In recent years mechanization has gained considerable importance in tea cultivation due to the non availability of adequate number of workers for harvesting especially during the two high cropping seasons. Therefore, it has become necessary to mechanize this operation not only to increase the productivity of the workers but also to reduce the cost of production. In the past, investigations had been carried out on the use of different makes mechanical harvesters (Pandiaraj, 1991: Sreedhar et al., 1997). But, due to various reasons the industry did not purse the use of mechanical harvesting in large scale.

A major difficulty in mechanizing plucking process is the steep and irregular slopes on which tea is very often grown. Much of the tea areas in India are subject to this drawback. Tea grown on undulating land, can however be mechanically harvested. The hedge-trimming shears can be used on the hilly terrain. A good deal of interest on mechanical harvesting has grown in countries viz. Japan, Mauritius, former USSR, Argentina, south Africa, Zimbabwe, Uganda, Kenya, Malawi, Australia and Papua New Guinea some of these countries are already using mechanical harvesting on a large scale.

\section{Materials}

\section{Materials And Methods}

Clonal cultivars UPASI-3, UPASI-9, UPASI-17 and seedling Assam and China jats have been selected for this experiment in twenty five different plots. The investigation was conducted from April 2013 to March 2014 in the agro climatic conditions in Coonoor Tea Estates Company Limited, Coonoor, Nilgiris and the altitude 1800 MSL.

The shear harvesting technique was developed in south India by UPASI. The blade consists of blunt knife, made from galvanized steel, positioned $15 \mathrm{~mm}$ above a horizontal aluminum platform or base plate. The blade is held in one hand 
so that the platform rests on the bush surface. The blade is then moved towards the operator, who uses the other hand to guide shoots in to the path of the knife, where they are broken, the weight of shear is $0.800 \mathrm{~g}$.

Harvesting methods based on simple mechanical aids (blade and shear) were evaluated against hand harvesting on mature morphologically-contrasting tea clones and seedlings. The modified one man operated Kwasaki harvester (model NV $45 \mathrm{H}$ ) is a shoulder mounted harvester with reciprocating type of blade. The blade length is $45 \mathrm{~cm}$ and the total weight of the machine is $9.5 \mathrm{~kg}$. The machine is run by a mixture of petrol and 2 stroke oil. The two men operated Kawasaki harvester (model SV $140 \mathrm{H}$ ) is a hand held harvester with reciprocating blade. The blade is $140 \mathrm{~cm}$ long and the machine weight 14.5 $\mathrm{kg}$. The machine is run by a mixture of petrol and 2 stroke oil

\section{Methods}

A part of the Harvested leaves was used for the analysis of biochemical parameters. Total polyphenol were estimated by using the producer of Dev Choudry and Goswami (1983) and the total catechins were analysed by using the method of Swain and Hillis (1959). Chlorophyll and +carotenoids were estimated by the method of Wellburn (1994). Lipid and fatty acids were analysed by following the procedure described by (Ravichandran and Parthiban 2000).

A part of the crop shoots harvested from the cultivars were withered at a thickness of $20 \mathrm{~cm}$ with an air flow of 30 $\mathrm{ft}^{3} / \mathrm{min} / \mathrm{kg}$ of leaves for 16 hour to obtain a moisture content of $65 \%$. The relative humidity was $87 \%$, the maximum and minimum temperatures of 28 and $18{ }^{\circ} \mathrm{C}$. The withered leaves were passed through a crush, tear and curl (CTC) rolling for complete maceration for five-cut system. The machine-rolled leaves were fermented in a continuously rotating aluminium drum for $1 \mathrm{hr}$ Ullah (1977). Dholl passed through drier in a fluid-bed drier at $115^{\circ} \mathrm{C}$ for 25 minutes with hot air to obtain black tea containing 3\% moisture. Drier mouth tea (DMT) passing between sieves BSS 30 mesh grade was taken for analysis.

Theaflavins, thearubigins and total liquor colour were measured by the method of Thangaraj and Seshadri (1990). The water extract was estimated as per Indian Standards (1999) and crude fibre content by the International Organization for Standardization (1999). Lipid fractions and fatty acids were analysed by following procedure described by (Ravichandran and parthiban, 2000). Integrated harvesting methods adopted five different experiment plots were under the treatments. The experiment was initiated in April 2013 to March 2014. Each treatment consisted of five replications. Plucking interval was followed as per the standard recommendation of UPASI Scientific Department (Table 1) (Satyanarayana et al., 1990; Victor Ilango et al., 2001). Plucking interval was followed by cropping patter.

\section{Results And Discussion}

Total number of plucking rounds per year in different treatment is given in (Table 1). Integrated schedule of harvesting using hand shears was the highest among the treatments ( 24 rounds). The plucking rounds were shorter due to the retention of sufficient number of immature buds while shear harvesting. The one man operated machine retained large number of shoots with one leaf and bud but harvested majority of shoots with two leaves and a bud. Therefore, the number of plucking rounds was less when one man operated machines were used (17 rounds). The two men operated machines due to their heavy weight harvested majority of shoots with one and two leaves. Consequently, the plucking intervals were extended (16 rounds).

The green leaf harvested by use of machine much higher than that by shear-harvesting. Machine harvesting leads to a reduction in plucker requirement. The use of machine increased the plucking interval and decreased the productivity. However the decrease in productivity was not significant. The field observation showed poor leaf distribution in machine distribution in machine operated fields. Machine harvesting collected more coarse leaf, black leaf, mechanically injured leaves than intact standard leaf, while the shear-harvest contained only three leaves and a bud less percentage of black leaf and coarse leaf. Machine harvesting is non selective and removes all available shoots, even immature ones, which could grow into the next generation of shoots within a short interval (Graph 1).

The yield data indicated statically significant differences among the different treatments; even though the integrated schedule of harvesting using one man and two men operated machines resulted in significant depression in yield when compared to shear harvesting. The different treatments on yield are presented in (Graph 2). Green leaf biochemical parameter such as total polyphenols, catechins was decline due to machine harvesting; this reflects the decline in black tea quality. The chlorophyll, total lipid and protein marginally decreased from shear plucked leaves much higher than that obtained from machine harvesting leaves. Biochemical parameters decreased for the clonal UPASI 9, UPASI 3 and followed by UPASI 7. For the seedlings assam followed by china also decline by using the machine harvesting (Table 2).

The marginal decline in black tea quality parameters due to style of harvesting, theaflavins an important quality parameter, which are directly correlated with quality, thearubigins, are seen decrease with machine harvesting. The quality parameter such as lipid, protein, Carotenoids and caffeine content is marginally decreased (Table 3 ). The crude fiber content increased with machine harvesting. Total ash and water extracts level also slightly decreasing. The water extract value, which determines the cuppage value also declined with shearing. Highly polymerized substance and total liquor colour which are undesirable beyond a certain value. The tea tasters rated the black tea form shear plucked leaves much higher than that obtained from machine harvesting leaves. They commented that both flavor and color of tea infusion obtained from shear plucked leaves were distinctly higher than those obtained by machine harvesting, for the clonal UPASI 9, UPASI 3 and followed by UPASI 7. For the seedlings assam followed by china also decline by using the machine harvesting (Table 4). The taster sore also decline due to style harvesting.

\section{Conclusion:}

Based on this study, it is recommended that is integrated schedule of harvesting using both the one and two man operated machines may be implemented in fields when they are more than three month or six month from pruning. The 
manpower shortage new schedule of integrated harvesting system, it is may helps to achieve optimal production, quality and profitability in south Indian tea industries. It could also be argued that mechanical harvesting; capable of harvesting tender shoots only could achieved by arising the plucking height at definite intervals. The mechanical harvesting over several years might change the plucking table, allowing only three leaf and buds to emerge out of the plucking table and keeping the mother leaf uniformly in a plain, horizontal level, thereby allowing the harvest tender shoots alone. The present data obtained on the changes in quality parameters of both green leaf and black tea, obtained by machine harvesting from fields under continual machine harvesting over several years, are presented the various tables one man and two men harvesting machine, all the quality parameters were found to improve and very close to the integrated shear harvesting. Present data showing that the quality deterioration with time normalizes continuous machine harvesting and adverse impact on bush physiology and production.

\section{Acknowledgements}

The author would like to thank Dr, K. Anbarasu, Principal, National College Tiruchirappalli and Mr. Jebakumar, Vice President. (Plantations), The Coonoor Tea Estate Company Limited, for their encouragement and necessary facilities for this investigation. Our sincere thanks are due to Dr. Radhakrishna Director and Dr. R. Victor J. Ilango, Joint Director, Botanist, UPASI Tea Research Foundation, Valparai, for their constant encouragement.

\section{Reference}

[1]. Baruah, S., Hazarika, M., Mahanta, P.K., Horita, H. and Murai, T. 1896. Effect of plucking intervals on the chemical constituents of CTC black teas. Agricultural and biochemical Chemistry 50,1039-1041.

[2]. Dev Choudhury, M.N. and Goswami, M.R., 1983. A rapid method for the estimation of total polyphenolic matters in tea (Camellia sinensis L.). Two and A Bud., 30: 59-61.

[3]. Forrest, G. T., and Bendall, D.S., 1969. The distribution of polyphenols in the tea plant(Camellia sinensis L.) Biochem.J. 33: 741755.

[4]. Mamedov, M.A., and Dzhafarof, B.S. 1974. Tea productivity in relation to hard plucking (In Russian). Sub trop. Kul'tury 2: 3-5.

[5]. Owour,P.O., Obanda, A.M., Othieno, C.O., Horita, H., Tsushida, T. and Murai, T. 1987. Changes in the chemical composition and quality of black tea due to plucking standards. Agriculture and Biological Chemistry 51, 3383-3384.

[6]. Palmer-Jones, R.W. 1977. Effect of plucking policies on the yield of tea in Malawi. Experimental Agriculture 13, 43-49.

[7]. Pandiaraj, G.T.S. 1991. Motorised mechanical harvesting, Bulletin of UPASI Scientific Department 44: 35-39.

[8]. Ravichandran, R., and Parthiban, R. 2000. Lipid occurrence, distribution and degradation to flavor volatiles during tea processing. Food chemistry, 68, 7-13.

[9]. Satyanarayana, N., Spurgeon Cox, Govindarajulu, V., Surendra Mohan, M., Hudson, J.B. and Sharma, V.S. 1990. Implications of mechanical harvesting in tea . Planters' Chronicle 85: 59-72.

[10]. Sreedhar, Ch., Victor J Ilango, R. and Sasidhar, R. 1997. Mechanisation of field operation in tea culture. Bulletin of UPASI Scientific Department 50: 8-19.

[11]. Swain, T and Hillis, W.E., 1959. The phenolic constituents of prunus domestica. I. The quantitative analysis of phenolic constituents. J. Sci. Food Agric. 10: 63-68

[12]. Thanaraj, S.N.S. and Seshadri, R., 1990. Influence of polyphenol oxidase activity and polyphenol content of tea shoot on quality of black tea. J .Sci. Food Agric. 51: 57-69.

[13]. Ullah, M. R, 1997. Alternative test for assessment of fermentation, Proceedings of Tocklai Conference. 29 75-77.

[14]. Victor Ilango, R.J., Ajayakumar, K., Muraleedharan, N., Rajkumar. R., Marimuthu, S. and Senthilkumar, R.S. 2001. Field evaluation of motorised harvesters in tea. Bulletin of UPASI Tea Research Foundation No. pp. 1-13.

[15]. Wellburn, A.R., 1994. The spectral determination of chlorophylls a and b as well as total carotenoids, using various solvents with spectrophotometers of different resolution. J. Plant Physiol. 144: 307-313.

[16]. Wight, W. 1959. Nomenculture and classification of the tea plant. Nature, 183: 1726-1728.

Table 1. Influence of harvesting schedules on plucking months.

\begin{tabular}{|c|c|c|c|c|c|c|}
\hline \multirow[b]{3}{*}{ Treatments } & \multicolumn{3}{|c|}{ Year } & \multicolumn{3}{|c|}{ Year } \\
\hline & Harv & sting schedul & & & Rour & \\
\hline & H P & S H & $\begin{array}{c}\text { M H } \\
\text { (Single / Two men) }\end{array}$ & H P & S H & M H \\
\hline $\begin{array}{l}\text { 1. Integrated schedule of shear } \\
\text { Harvesting }\end{array}$ & $\begin{array}{l}\text { Dec,-March } \\
\text { July-Aug, }\end{array}$ & $\begin{array}{l}\text { April-June } \\
\text { Sept,-Nov, }\end{array}$ & & 14 & 10 & 24 \\
\hline $\begin{array}{l}\text { 2. Integrated schedule of harvesting } \\
\text { using single man operated machine }\end{array}$ & & $\begin{array}{l}\text { Dec,-March } \\
\text { July- Aug, }\end{array}$ & $\begin{array}{l}\text { April-June } \\
\text { Sept,-Nov, }\end{array}$ & 10 & 7 & 17 \\
\hline $\begin{array}{l}\text { 3. Integrated schedule of harvesting } \\
\text { using two men operated machine }\end{array}$ & & $\begin{array}{l}\text { Dec,-March } \\
\text { July- Aug, }\end{array}$ & $\begin{array}{l}\text { Apr,-Jun } \\
\text { Sept,-Nov, }\end{array}$ & 10 & 6 & 16 \\
\hline $\begin{array}{l}\text { 4. Continual harvesting using one } \\
\text { man operated machine }\end{array}$ & & & Jan, - Dec, & 14 & & 14 \\
\hline $\begin{array}{l}\text { 5. Continual harvesting using two } \\
\text { Men operated machine }\end{array}$ & & & Jan, - Dec, & 14 & & 14 \\
\hline
\end{tabular}


Impact of modernization of harvesting in tea plantation to improve the productivity and ...

Table 2. Changes in green leaf biochemical constituents due to style of harvesting.

\begin{tabular}{|c|c|c|c|c|c|c|c|}
\hline $\begin{array}{l}\text { Style of } \\
\text { harvesting }\end{array}$ & Cultivars & $\begin{array}{c}\text { Polyphenols } \\
\%\end{array}$ & $\begin{array}{l}\text { Catechins } \\
\%\end{array}$ & $\begin{array}{l}\text { Chlorophyll a } \\
\text { (mg/g) }\end{array}$ & $\begin{array}{l}\text { Chlorophyll b } \\
\text { (mg/g) }\end{array}$ & $\begin{array}{l}\text { Lipid } \\
\%\end{array}$ & $\begin{array}{l}\text { Protein } \\
\%\end{array}$ \\
\hline \multirow{5}{*}{$\begin{array}{l}\text { Int, hand } \\
\text { plucking }\end{array}$} & UP 3 & 29.7 & 19.5 & 1106 & 523 & 7.5 & 15.7 \\
\hline & UP 9 & 30.6 & 20.3 & 1231 & 561 & 8.7 & 16.9 \\
\hline & UP 17 & 28.1 & 18.5 & 996 & 481 & 6.1 & 14.3 \\
\hline & Assam & 27.3 & 17.4 & 981 & 475 & 5.8 & 13.1 \\
\hline & China & 26.1 & 16.3 & 863 & 423 & 5.0 & 12.9 \\
\hline \multirow{5}{*}{$\begin{array}{l}\text { Single man } \\
\text { harvesting }\end{array}$} & UP 3 & 27.5 & 17.3 & 1091 & 501 & 6.3 & 14.9 \\
\hline & UP 9 & 28.6 & 18.5 & 1147 & 520 & 7.4 & 15.6 \\
\hline & UP 17 & 26.3 & 16.1 & 1051 & 487 & 5.9 & 13.9 \\
\hline & Assam & 25.6 & 15.8 & 1009 & 481 & 5.0 & 12.7 \\
\hline & China & 24.9 & 14.9 & 988 & 463 & 4.8 & 12.0 \\
\hline \multirow{6}{*}{$\begin{array}{l}\text { Two men } \\
\text { Harvesting }\end{array}$} & UP 3 & 25.3 & 15.1 & 1073 & 495 & 5.7 & 14.1 \\
\hline & UP 9 & 27.3 & 17.2 & 1102 & 505 & 6.1 & 14.3 \\
\hline & UP 17 & 24.1 & 14.9 & 1001 & 466 & 5.1 & 13.4 \\
\hline & Assam & 23.6 & 12.4 & 989 & 474 & 4.8 & 12.0 \\
\hline & China & 23.2 & 13.1 & 973 & 451 & 3.9 & 11.9 \\
\hline & Mean & 26.61 & 16.53 & 1046 & 497 & 5.6 & 13.8 \\
\hline \multicolumn{8}{|c|}{ Statistical significance (C.D. at $P=0.05$ ): } \\
\hline \multicolumn{2}{|c|}{ Between cultivars (C) } & 0.108 & 0.016 & 11.14 & 28.41 & 0.176 & 0.202 \\
\hline \multicolumn{2}{|c|}{ Between harvesting (S) } & 0.165 & 0.025 & 17.02 & 43.40 & 0.269 & 0.310 \\
\hline \multicolumn{2}{|c|}{ Interactions (CXS) } & 0.264 & 0.040 & 27.20 & 69.37 & 0.430 & 0.459 \\
\hline \multicolumn{2}{|c|}{ C.V $(\%)$} & 0.592 & 0.147 & 1.548 & 8.30 & 4.576 & 2.131 \\
\hline
\end{tabular}

Table 3. Changes in black tea parameter due to style of harvesting.

\begin{tabular}{|c|c|c|c|c|c|c|}
\hline $\begin{array}{l}\text { Style of } \\
\text { harvesting }\end{array}$ & Cultivars & $\begin{array}{c}\text { Theaflavins } \\
\%\end{array}$ & $\begin{array}{c}\text { Thearubigins } \\
\%\end{array}$ & $\begin{array}{c}\text { Caffeine } \\
\%\end{array}$ & $\begin{array}{c}\text { Amino acid } \\
\%\end{array}$ & $\begin{array}{l}\text { Carotenoids } \\
(\mathrm{mg} / \mathrm{g})\end{array}$ \\
\hline Int, hand & UP 3 & 0.89 & 8.10 & 4.30 & 3.89 & 83 \\
\hline \multirow{4}{*}{ plucking } & UP 9 & 0.93 & 9.23 & 4.85 & 3.99 & 87 \\
\hline & UP 17 & 0.82 & 7.90 & 4.10 & 3.87 & 79 \\
\hline & Assam & 0.76 & 7.10 & 3.95 & 3.79 & 63 \\
\hline & China & 0.71 & 7.01 & 3.45 & 3.56 & 59 \\
\hline Single man & UP 3 & 0.85 & 8.00 & 4.00 & 3.76 & 76 \\
\hline \multirow{4}{*}{ harvesting } & UP 9 & 0.86 & 9.00 & 4.62 & 3.79 & 73 \\
\hline & UP 17 & 0.76 & 7.80 & 3.90 & 3.72 & 67 \\
\hline & Assam & 0.69 & 6.80 & 3.60 & 3.63 & 59 \\
\hline & China & 0.67 & 6.73 & 3.16 & 3.60 & 55 \\
\hline Two men & UP 3 & 0.82 & 7.96 & 3.90 & 3.73 & 69 \\
\hline \multirow[t]{5}{*}{ Harvesting } & UP 9 & 0.80 & 8.92 & 4.41 & 3.75 & 68 \\
\hline & UP 17 & 0.71 & 7.60 & 3.70 & 3.71 & 60 \\
\hline & Assam & 0.65 & 6.63 & 3.41 & 3.64 & 53 \\
\hline & China & 0.63 & 6.51 & 3.00 & 3.60 & 49 \\
\hline & Mean & 0.76 & 7.70 & 3.90 & 3.74 & 69 \\
\hline \multicolumn{7}{|c|}{ Statistical significance (C.D. at $P=0.05$ ): } \\
\hline \multicolumn{2}{|c|}{ Between cultivars (C) } & 0.014 & 0.078 & 0.576 & 0.070 & 0.594 \\
\hline \multicolumn{2}{|c|}{ Between harvesting (S) } & 0.022 & 0.120 & 0.880 & 0.107 & 0.907 \\
\hline \multicolumn{2}{|c|}{ Interactions (CXS) } & 0.036 & 0.192 & 0.140 & 0.171 & 1.450 \\
\hline \multicolumn{2}{|c|}{ C.V $(\%)$} & 2.818 & 1.487 & 2.145 & 2.733 & 1.250 \\
\hline
\end{tabular}


Impact of modernization of harvesting in tea plantation to improve the productivity and ...

Table 4. Changes in black tea parameter due to style of harvesting.

\begin{tabular}{|c|c|c|c|c|c|c|}
\hline $\begin{array}{l}\text { Style of } \\
\text { harvesting }\end{array}$ & Cultivars & $\begin{array}{l}\text { Total ash } \\
\%\end{array}$ & $\begin{array}{c}\text { Crude fiber } \\
\%\end{array}$ & $\begin{array}{l}\text { HPS } \\
\%\end{array}$ & TLC & $\begin{array}{c}\text { Water extract } \\
\%\end{array}$ \\
\hline $\begin{array}{l}\text { Int, hand } \\
\text { plucking }\end{array}$ & $\begin{array}{l}\text { UP } 3 \\
\text { UP } 9 \\
\text { UP } 17 \\
\text { Assam } \\
\text { China }\end{array}$ & $\begin{array}{l}16.31 \\
17.20 \\
15.92 \\
15.30 \\
14.90\end{array}$ & $\begin{array}{l}15.45 \\
16.45 \\
14.90 \\
13.60 \\
14.10\end{array}$ & $\begin{array}{l}8.15 \\
9.23 \\
8.10 \\
7.95 \\
7.13\end{array}$ & $\begin{array}{l}3.01 \\
3.40 \\
3.10 \\
2.95 \\
2.63\end{array}$ & $\begin{array}{l}42.30 \\
43.50 \\
41.10 \\
40.10 \\
39.16\end{array}$ \\
\hline $\begin{array}{l}\text { Single man } \\
\text { harvesting }\end{array}$ & $\begin{array}{l}\text { UP } 3 \\
\text { UP } 9 \\
\text { UP } 17 \\
\text { Assam } \\
\text { China }\end{array}$ & $\begin{array}{l}15.90 \\
16.40 \\
15.94 \\
15.10 \\
14.73\end{array}$ & $\begin{array}{l}15.60 \\
16.39 \\
14.60 \\
14.20 \\
14.30\end{array}$ & $\begin{array}{l}8.10 \\
9.00 \\
8.05 \\
7.80 \\
7.26\end{array}$ & $\begin{array}{l}2.95 \\
3.01 \\
2.96 \\
2.76 \\
2.46\end{array}$ & $\begin{array}{l}41.00 \\
40.10 \\
40.00 \\
39.60 \\
38.27\end{array}$ \\
\hline $\begin{array}{l}\text { Two men } \\
\text { Harvesting }\end{array}$ & $\begin{array}{l}\text { UP } 3 \\
\text { UP } 9 \\
\text { UP } 17 \\
\text { Assam } \\
\text { China } \\
\text { Mean }\end{array}$ & $\begin{array}{l}15.60 \\
15.90 \\
15.97 \\
14.95 \\
14.21 \\
15.42\end{array}$ & $\begin{array}{l}15.90 \\
15.91 \\
14.10 \\
14.07 \\
14.00 \\
14.93\end{array}$ & $\begin{array}{l}8.00 \\
8.50 \\
7.95 \\
7.60 \\
7.01 \\
7.96\end{array}$ & $\begin{array}{l}2.80 \\
2.85 \\
2.80 \\
2.41 \\
2.04 \\
2.78\end{array}$ & $\begin{array}{l}40.01 \\
39.70 \\
39.20 \\
38.20 \\
37.76 \\
40.00\end{array}$ \\
\hline $\begin{array}{l}\text { Statistical signi } \\
\text { Between cultiva } \\
\text { Between harves } \\
\text { Interactions (C) } \\
\text { C.V }(\%)\end{array}$ & $\begin{array}{l}\text { ance (C.D. a } \\
\text { (C) } \\
\text { ag (S) }\end{array}$ & $\begin{array}{l}=0.05): \\
0.147 \\
0.225 \\
0.360 \\
1.391\end{array}$ & $\begin{array}{l}0.776 \\
0.118 \\
0.189 \\
0.755\end{array}$ & $\begin{array}{l}0.055 \\
0.084 \\
0.134 \\
1.006\end{array}$ & $\begin{array}{l}0.103 \\
0.157 \\
0.251 \\
5.374\end{array}$ & $\begin{array}{l}0.301 \\
0.461 \\
0.737 \\
1.097\end{array}$ \\
\hline
\end{tabular}

Graph 1. Comparative analysis of green leaf harvesting method of tea cultivars.

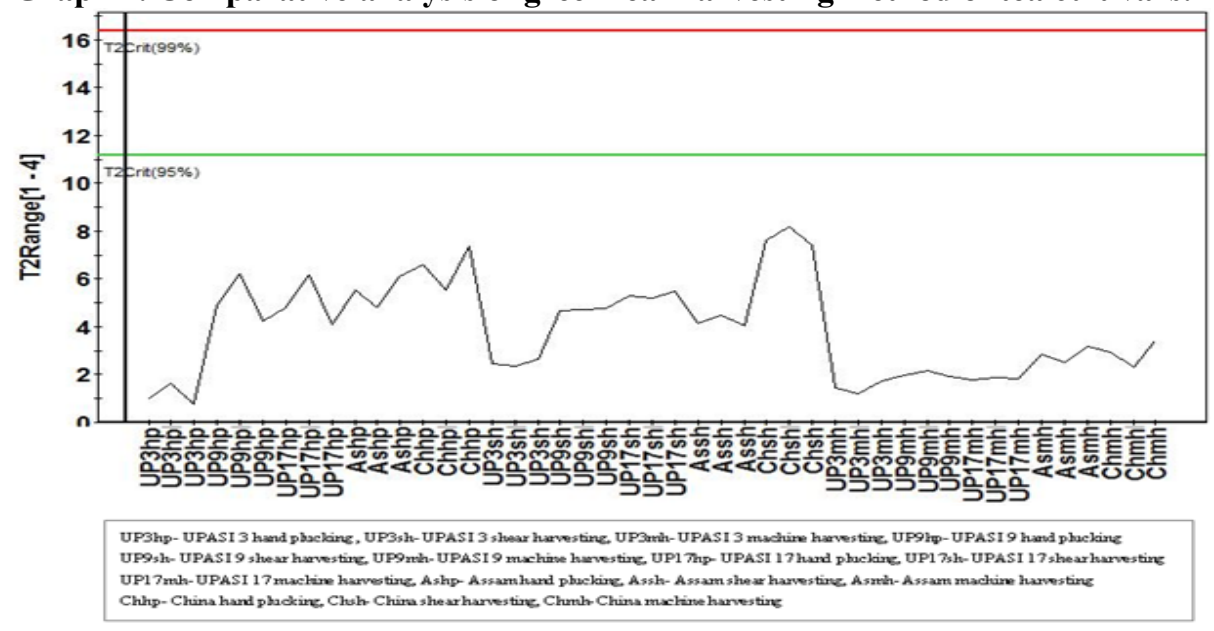

Graph 2. Yield difference for the different type of harvesting style.

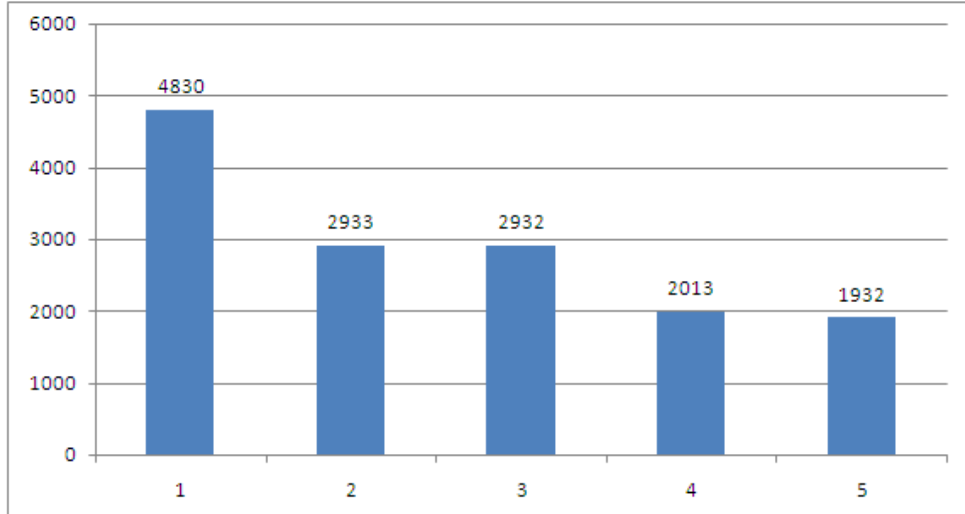

1. Integrated schedule of shear Harvesting, 2. Integrated schedule of harvesting using single man operated machine, 3. Integrated schedule of harvesting using two men operated machine ,

4. Continual harvesting using one man operated machine, 5. Continual harvesting using two

Men operated machine 